\title{
E-COMMERCE Live STREAMing - An EMERging INDUSTRY IN CHINA ANd a Potential Future Trend in THe World
}

\author{
Yang Lu ${ }^{1}$; Patrick Siegfried ${ }^{2}$ \\ ${ }^{1}$ Frankfurt School of Finance and Management, \\ BSc Business Administration Class 2021, \\ Europa-Allee 103, 60486, Frankfurt am Main, Germany \\ ${ }^{2}$ International School of Management (ISM), \\ Department of International Logistics and Supply Chain Management, \\ Mörfelder Landstraße 55, 60598, Frankfurt am Main, Germany \\ e-mail: ${ }^{1}$ yang.lu@fs-students.de; ${ }^{2}$ patrick.siegfried@ism.de
}

\begin{abstract}
With the widespread use of the Internet, many industries have developed rapidly. The economy based on the Internet poses a significant threat to the traditional economy. Live streaming plus e-commerce, which is acknowledged as the current global economic status, is the result of combing live streaming and various industries through the Internet.

E-commerce live streaming is one of the most essential types of online live streaming. In this article, it is defined as the live streaming of the e-commerce platform used by Key Opinion Leaders or product sellers through the built-in live streaming function of the platform to propagate goods, brands, events, etc. to achieve goals of brand exposure and product sales. Compared with the traditional economic model, the combined model of e-commerce and live streaming has its advantages and characteristics. This kind of marketing tool is now prevalent. However, there are many deficiencies in e-commerce live streaming that need to be improved since the development of e-commerce is immature and supervision of Internet use is ongoing.
\end{abstract}

\section{Keywords}

Consumer behavior; Digital and social media; E-commerce live streaming; New media marketing.

\section{Introduction}

Since the '90s, the emergence of e-commerce on a global scale has been changing the existing economic structure fast, as well as the traditional economic growth model and the operation mode. E-commerce, as a new economic model, has shown high potential and has become an essential indicator regarding the level of economic development and sustainability of each nation. Today, live streaming, as a new trend, is naturally known to everyone. It has been the topic of relish due to its trending popularity, various forms, and diverse platforms. Live streaming has all advantages of the network resources, such as fast speed, convenience, and interaction where global e-commerce has presented a colorful pattern. Audiences are involved hence they create interests, which satisfy their interests through using live streaming to advertise or report products. Surprisingly, the growing live streaming business combined with various industries operating through the Internet has developed rapidly worldwide, especially in China. They have formed a global economic phenomenon 'live streaming plus economy'. Since the phenomenon of live streaming has been quite common, some online marketing agents begin to take full advantage of the broadcast to promote their sales. Compared with the 
traditional marketing channels, live streaming has played a more and more critical role in marketing in the global market.

As an essential infrastructure for the new era of the $21^{\text {st }}$ century, network construction has been attached with great importance in China. In the last six years when 4G was officially deployed and used, China's 4G Internet has reached the leading global level in terms of scale and coverage. The $2^{\text {nd }}$ version of 'Completion of the leading indicators of the communications industry from January to May 2020' published by the Ministry of Industry and Information Technology of China, shows that the number of mobile phone users in China has reached 1.592 billion, of which 1.279 billion are 4G users, and the number of mobile Internet users has reached incredible 1.319 billion.

From the data point of view, China is indeed a country with veritable mobile Internet, and its network infrastructure is relatively complete. With the world's most significant number of network users and massive network resources, the $4 \mathrm{G}$ network in China, has covered $98 \%$ of the country's population [1].

With the extensive promotion and popularization of the $4 \mathrm{G}$ mobile Internet, the high penetration rate of the Wi-Fi wireless network, and the high ownership rate of mobile smart devices, China's e-commerce has transformed from the PC era to the mobile network era. With the help of technological development, e-commerce live streaming grew explosively in 2019, with a transaction volume of about 440 billion CNY (55 billion EUR) [2].

\section{$1 \quad$ Research Objectives}

The live streaming platform's earliest content fields are the showing and the gaming industry, and there is little involvement in other fields. With the development of mobile Internet and the popularization of smart hardware, users gradually get rid of time and space limitations and can use their mobile devices to live stream and watch the live streaming at any time. The live streaming platform's content also began to expand into education, finance, e-commerce, sports, automotive, and other industries, which indicates that it has entered the era of 'live streaming plus'.

Prior studies of e-commerce live streaming found out that the scale of e-commerce live streaming transactions in China would reach 961 billion CNY (120.125 billion EUR) in 2020 while the growth rate will reach $111 \%$ [3]. The number of live streaming content creators has also increased significantly. Post-90s and post-95s generations have become core users of live streaming platforms [4]. The online live streaming platform has subverted the traditional way of information dissemination and opened a new milestone for real-time interaction of disseminated information. This feature of online live streaming has gradually been sought after by e-commerce platforms. From a strategic point of view, live streaming is a means for e-commerce platforms to carry out branding and infrastructure construction. From the perspective of development trends, with the further spread of 5G, VR, and AI technology, ecommerce live streaming will be in a rapid development period in the next few years [5].

Although in just a few years, e-commerce live streaming, as an emerging industry, has developed extremely rapidly and successfully in China, there is currently a trend of slowing down, and the potential threats to its further development are also gradually revealed.

In this article, the authors will focus on China as the main object of discussion and Germany as the reference object, to better analyze the success factors of the smooth development of ecommerce live streaming in China and also the potential threats and obstacles for the future development. In the following, the article will be mainly divided into three main parts: 
In the first part of the article, we are going to introduce and analyze the development of Chinese e-commerce live streaming from the following aspects:

1. Related theories which can explain the current situation of e-commerce live streaming,

2. The rising reasons for e-commerce live streaming in comparison with traditional ecommerce and

3. A survey which can further prove the analysis from consumers' perspective.

In the second part, the authors will analyze why e-commerce live streaming does not rise in Germany currently.

In the last part, the authors will list the current potential problems of e-commerce live streaming and corresponding development strategies and suggestions based on the survey results and related literature.

\section{$2 \quad$ Related Theories}

Before analyzing the characteristics of e-commerce live streaming in detail, the following related theories can help us better understand the principles of its success.

\subsection{Agenda-Setting Theory}

The theory shows that although the mass media cannot determine people's views on a specific event, they can influence people's attention by arranging issues and therefore decide what people should think at a particular time [6]. As a kind of mass media, the e-commerce live streaming platform also has the same agenda-setting function, at least it will decide which products people should pay attention to during online shopping carnivals such as Chinese Singles Day (11/11) and Double 12 Day (12/12) and during other brand activities. In essence, it is also a kind of agenda-setting that influences the products that people pay attention to at a specific time, rather than influencing the user's opinions on the product itself.

\subsection{KOL Theory}

KOL, the abbreviation of Key Opinion Leader, is a concept in marketing. It is usually defined as people or organizations with more accurate product information, whose opinions are accepted and trusted by a relevant group of people. They also have a significant influence on the group of people's purchasing behavior.

The theory believed that the mass media had an irresistible and overpowering force. The information it transmitted was like a bullet hitting the human body, which could influence people's attitudes and opinions. The audience was completely passive under this scenario. People discovered that there were two levels of communication in the process of information dissemination. The mass media do not directly pass the information to the audience but pass information in the way of the link of opinion leaders [7].

During e-commerce live streaming, the streamers act as opinion leaders to pass the information to the general audience. At the same time, they also act as gatekeepers who decide what kind of information should be passed to the audience. The information chosen by live streamers will affect the consumer's opinions on purchasing the product. It can explain why those top streamers have so many fans, enormous appeal, and amazing sales figures.

\subsection{Spiral of Silence Theory}

This concept describes the following phenomenon: When people express their ideas and opinions and find out that the opinions, they agreed with, are widely welcome, they will 
actively participate, and such opinions will be more and more diffused; while when people find their opinions are not accepted by most of the people, they will remain silent even if they insist on this opinion. In this circumstance, their silence, in turn, increases the other party's strong insistence. In this cycle, one party's voice becomes more durable and more substantial, and the other party becomes weak [8].

During the e-commerce live streaming activity, live streamers always use this theory to lead the audience to make comments, most of the people will actively participate in obtaining corresponding benefits, a small number of people have different views, however, they eventually tend to converge theirs to the majorities due to the fear of isolation. On the other hand, live streamers will also use this theory to establish trust with most users and achieve the conversion from interaction to sales.

\subsection{Uses and Gratifications Theory}

The theory's significance is that it believes that the audience's media contact is an activity of selecting media content based on their own needs. This choice is a kind of 'subjective initiative' that can replace the viewpoint that 'audiences are passive' [9].

This theory is reflected in the e-commerce live streaming activity that before users need to buy goods, they must understand the product information. Through the live streaming function of the e-commerce platforms, the users' demand for a deep understanding of the products can be met, and therefore facilitating the final purchase behavior.

\section{$3 \quad$ Research Methods}

To analyze the attitude of Internet users towards e-commerce live streaming more objectively, the authors have conducted a survey, sent by e-mail from May to July 2020 and collected 201 valid questionnaires. Among the 201 participants, there were 99 males and 102 females. The age of the respondents of the survey is shown in graph in Figure 1.

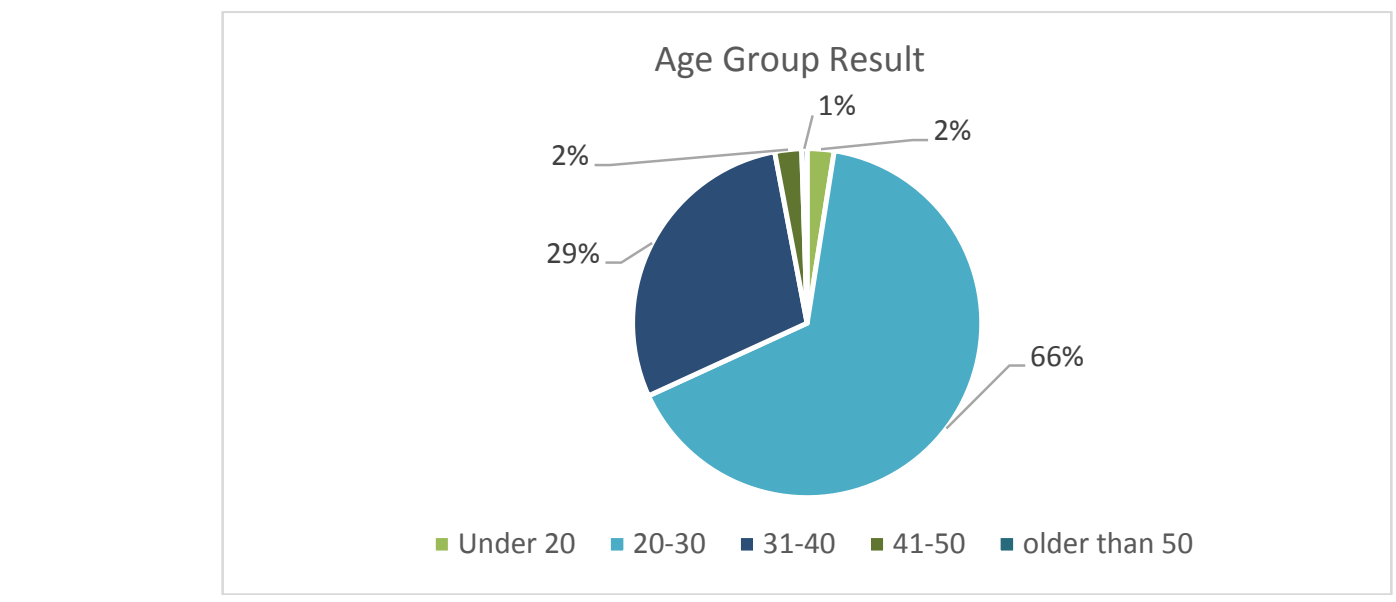

Source: Survey conducted by the authors

Fig. 1: Age of respondents in years

\section{$4 \quad$ Research Results}

One hundred and thirty-two people among them were between 20 to 30 years old, accounted for $66 \%$ of the total amount of interviewees. Most of them are students and young people who have just graduated or career freshmen. Fifty-eight people were between 31 to 40 years old. People in these age groups were all post-90s and 80s; most of them were usually curious about new things and liked to follow the trend. 


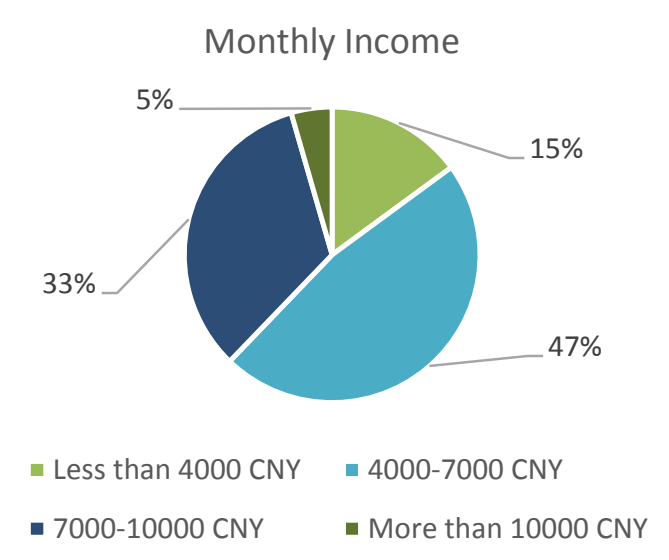

Source: Survey conducted by the authors

Fig. 2: Monthly income

According to survey data and shown in Figure 2, about $47 \%$ of all participants earned monthly between 4,000 (500 EUR) and 7,000 CNY (875 EUR), and about 33\% of them earned more than 7,000 (875 EUR) but less than 10,000 CNY (1,250 EUR) per month. In the average salary data for 2019, the annual average wage of persons employed in urban nonprivate units in China was 90,501 CNY (11,313 EUR), which is an increase compared to the annual average wage of 8,088 CNY (1,011 EUR) over the previous year, and it was 7,541 CNY (943 EUR) if converted to an average monthly salary. The annual average wage of persons employed in urban private units in China was 53,604 CNY (6,700 EUR), equivalent to 4,467 CNY (558 EUR) per month [10]. It shows that most of the participants' salary was at the upper-middle level of China's average salary.

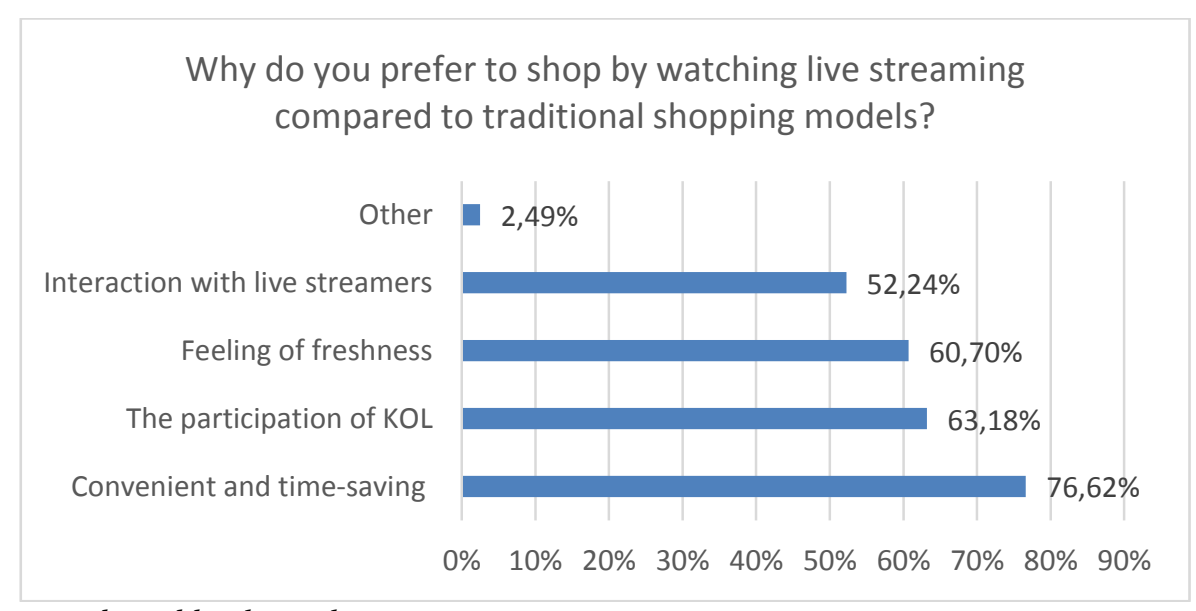

Source: Survey conducted by the authors

\section{Fig. 3: Reasons for watching e-commerce live streaming}

E-commerce live streaming shows as a new popular trend, see Figure 3, mainly because of its target audience, who are young generations of being post-80s and post-90s. The young generation has become the leading consumer group in China. According to data, in the 11th November (shopping festival in China), 2019, 55.9\% of respondents who aged from 22 to 25 years old (post-95s), used installment buying, with an increase of $70 \%$ from the previous year, and accounted for the largest share in all age groups, followed by the group of people aged from 26 to 29 years old (post-90s) [11].

Among the respondents to the questionnaire, $96 \%$ of people indicated that they liked watching live streaming sales, only nine people said they did not like watching them. Most consumers were more willing to shop by watching live streaming than traditional shopping models 
because live stream shopping is convenient and time-saving, as mentioned by $76.62 \%$ of participants. Besides, KOL's participation, feeling of freshness, and interaction with live streamers were also main reasons for them to choose live stream shopping. Some other people preferred to shop by watching live streams because they could receive much more discount coupons from the live room.

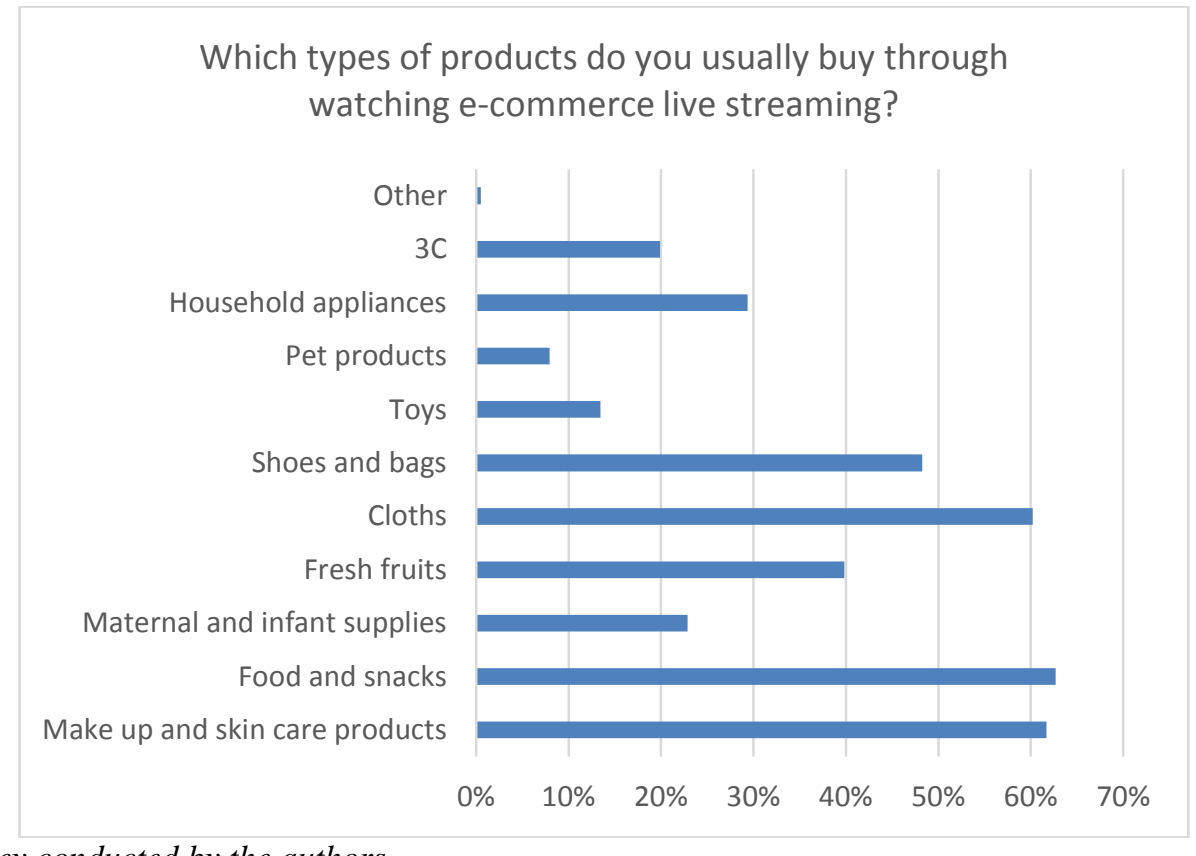

Source: Survey conducted by the authors

Fig. 4: Frequently bought types of products

By investigating the types of goods that Internet users purchase by watching e-commerce live streaming most often, we found that food and snacks, makeup, and skincare products, as well as clothes, shoes, and bags, are the most frequently bought things, see Figure 4.

According to data, China's snack food market size reaches 347,795 million CNY (44 million EUR) in 2020. The market is expected to grow annually by $5.5 \%$ [12]. The e-commerce sales amount of the snack industry in 2018 was 62.1 billion CNY (7762.5 million EUR), with a year-on-year increase of $23.4 \%$. Euromonitor International data shows that supermarket is still the primary sales channel of food and snacks, accounting for $60 \%$ in the whole market, followed by chain stores. Though the proportion of the sales of the e-commerce channel is not the largest, it is increasing quickly in the past few years [13].

In 2018, e-commerce became the largest sales tool for cosmetics and skincare in China, followed by supermarkets and department stores. According to data from the National Bureau of Statistics, from January to October 2019, the total retail sales of cosmetics in social consumer goods was 238.2 billion CNY (29,775 million EUR) with a year-on-year growth rate of $12.1 \%$. The total e-commerce sales of cosmetics will likely reach a hundred billion CNY (12.5 billion EUR) in 2020.

At present, the leading e-commerce platforms in the clothing industry are still traditional platforms such as Taobao, Tmall, JD, and Vipshop. It is estimated that the proportion of social e-commerce platforms such as TikTok, Kuaishou will continue to increase in the future. Reasons for this are, on the one hand, traditional e-commerce is facing exhaustion of traffic, and social e-commerce uses social networks to achieve low-cost referral traffic; on the other hand, social e-commerce facilitates purchases through consumers' trust with a high conversion rate. 
However, now it is evident that live streaming coverage is getting wider, from 3C digital products (Computer, Communication, and Consumer Electronics) and household appliances to automobiles, and real estate, all frequently appeared in live rooms.

In April 2020, Yonghao Luo, who is one of the first generations of Internet celebrities, has completed his first live stream in TikTok. Unlike other live streamers, the major subscribers of Luo are males, so he focuses more on 3C digital products in goods selection. According to the data, his entire live stream lasted 3 hours, the total payment transaction exceeded 110 million CNY (13.75 million EUR) and cumulated more than 48 million viewers. Luo set the known highest live stream sales record on the TikTok platform. On the same day, Viya even sold rockets in her live room. Only with 5 minutes, more than 800 people paid deposits, and transactions were finally successfully concluded [14].

How often do you shop by watching live streaming?

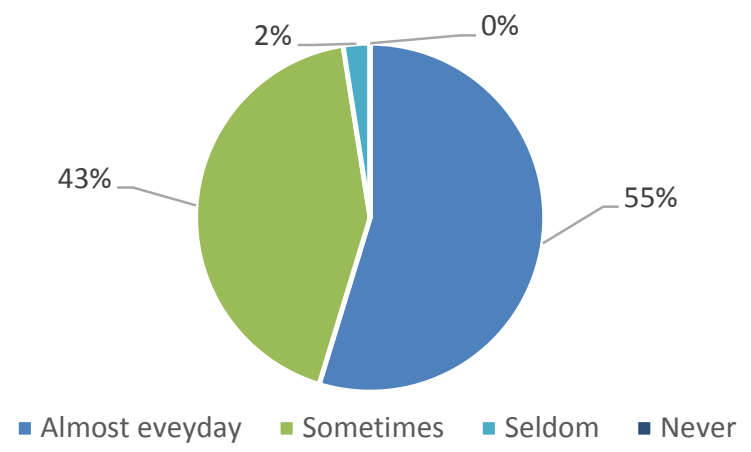

Source: Survey conducted by the authors

Fig. 5: Frequency of watching live streaming

According to the survey, 110 out of 201 participants shop by watching live streaming almost every day, see Figure 5, which suggests that over $54.73 \%$ of people show the strong intention of using such modern tool while the remaining proportion of people shows less intention of using the live streaming tools. However, none of the participants has ever watched ecommerce live streaming, which again proves the view that e-commerce live streaming is increasing fast enough in the young generation's lives.

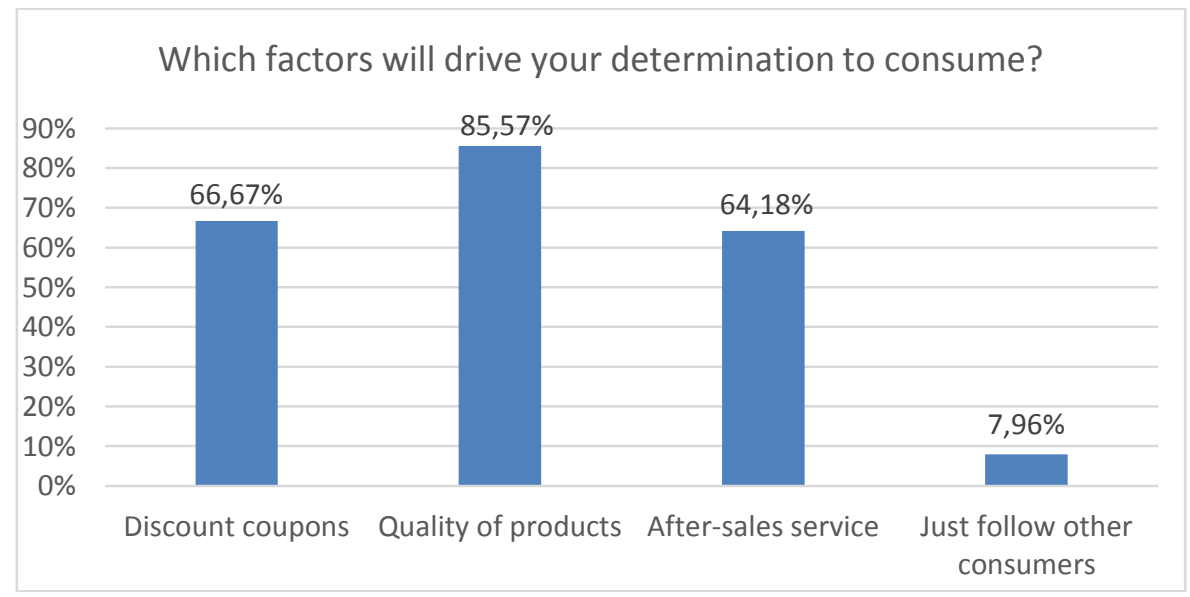

Source: Survey conducted by the authors

Fig. 6: Determinant factors of promoting consumption

Among the respondents, see Figure $6,85.57 \%$ of people indicated that high quality of goods was the primary reason for them to consume or purchase, while some other factors such as 
discount coupons and after-sales service would also affect viewers' willingness to purchase. Compared to traditional e-commerce shopping, Internet users can have further understandings of products recommended by live streamers by watching e-commerce live streaming. However, it still cannot altogether avoid some bad shopping experiences caused by problems of product quality, delivery, and after-sales service. Indeed, several consumers do not consider so many factors, but are attracted by the intense time-limited buying activities in the live room and placed an order following the other consumers.

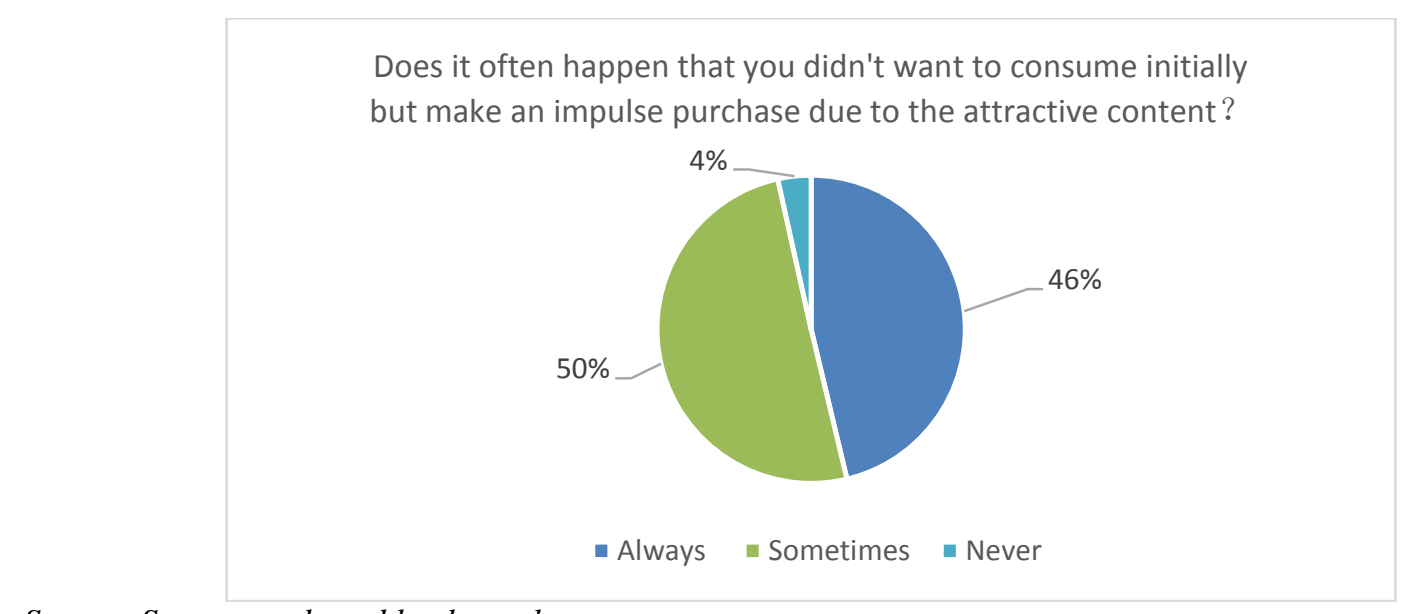

Source: Survey conducted by the authors

Fig. 7: Frequency of impulse purchase

More than half of these 201 participants indicated that impulse purchasing happens from time to time, which can be interpreted as they do not want to consume initially but make an impulse purchase due to the attractive content; In the survey, see Figure 7, only $4 \%$ of participants have never made an impulse purchase before. Thus, it proves that most people are emotional and impulsive when watching live stream sales. They will spend unnecessary money when they are emotional especially when there are big discounts, and many other viewers are snapping up in the live room. The psychology that stimulates users to pay is 'the conformity with a sense of urgency driven by interests'.

The participants showed that, from their experience, there is still much room for e-commerce live streaming shows to improve. According to data, the top three complaints about online consumption in 2020 in China are refund issues, shipping issues, and product quality, followed by other problems such as return issues, selling fakes and after-sales services, etc. [15].

As more and more consumers begin to focus on product quality, it proves that Chinese residents' economic conditions have been improved. The increase in residents' income has enhanced their material requirements. In recent years, competition in the e-commerce industry has become increasingly fierce. For each e-commerce platform, 'Quality' has even become the guarantee of platforms' core competitiveness.

Besides other things, consumers also pay more and more attention to the authenticity of products and after-sales service; it shows that with social development and the improvement of living standards, consumers' rights and self-protection awareness are getting enhanced.

\section{Reasons and Analysis of the Rise of e-Commerce Live Streaming Platforms}

In China, live streaming, as a technology output, just like Internet technology, is deeply penetrated to various fields. Sports, games, education, finance, automotive, and other industries can all be related to live streaming, so the model of 'live streaming plus' appeared. 
This chapter will primarily analyze the generation of the model 'E-commerce plus Live streaming' from the following aspects:

\subsection{Wanghong Economy (Internet Celebrity Economy), Celebrity Effect}

Wanghong economy is the nascent Chinese digital economy based on influencer marketing in social media, which can attract the attention of Internet users and convert into profit through e-commerce and online advertising.

The emergence of live streaming has provided new enlightenment for the transformation of ecommerce. Most of the live stream influencers are Internet celebrities and stars who attract many fans to follow, which can be easily understood as KOLs. The new marketing strategy has been formed through the combination of KOLs and e-commerce live streaming.

The famous cosmetics brand Maybelline New York had made use of live streaming in 2016. They invited Angelababy (a famous actress) and other 50 online celebrities to go on the broadcast together. According to the statistics, they sold 10,000 lipsticks in just 2 hours, and the sales are more than 1.4 million CNY (175,000 EUR) [16]. The new marketing model of 'live streaming plus economy' has prompted users to make consumption decisions, reduced the consumers' cost, made the users fully understand products, broken the space barriers, and improved the user's engagement and motivation.

According to data, nearly $40 \%$ of consumers were willing to purchase the products recommended by KOLs, among them, female users are more likely to be affected [17].

\subsection{Attract Consumer Traffic through Live Streaming}

For e-commerce companies, page views represent consumer traffic, and traffic is the basis for stores to achieve conversion. Therefore, e-commerce platforms always pay many efforts to attract consumers' attention, and they work harder when they find stimulation such as shopping festivals, discount coupons, clearance sales, etc. However, after the e-commerce industry entering the period of steady growth, these methods are not attractive enough to stimulate consumers. Since consumers are getting tired and confused by unpredicted price fluctuations, they are not interested and loyal to certain brands. In contrast, live streaming sales are very attractive to consumers. E-commerce live streaming can display products in all directions, and simultaneously, live streamers can interact with consumers in real-time to bring them a new shopping experience and thus effectively focusing user attention to import traffic for the stores.

\subsection{Obtain Consumers' Demands as Soon as Possible}

The core of the competition of e-commerce is the consumer. The quicker sellers accurately understand the trend and adapt to consumers' real needs, the more benefits they will get. Therefore, many companies have set user research departments to understand their target users better. E-commerce live streaming is highly interactive, and live streamers can communicate with consumers about products in real-time so that they can understand the user's needs and consumption preferences as soon as possible. Through the deep interaction, a relatively stable relationship will be built by both parties: Consumers are willing to express their real demands, and merchants who receive feedback can adjust the products in time to meet the needs, thus increasing the economic efficiency. Therefore, live streaming is a useful tool for e-commerce platforms to obtain user attributes and needs. 


\subsection{Real Product Information}

The primary way of traditional e-commerce to display products was pictures and texts. Although some platforms have started to use short videos to display product features, they failed to catch the real information to comprehensively estimate products. Besides, the texts, pictures, and videos were all carefully edited and modified before uploading to the platforms, which confused consumers about the real quality of the product. However, e-commerce live streaming broke the information asymmetry between sellers and consumers because it cannot be modified. Once the anchor starts live streaming, all product features and the anchor's behaviors will be exposed. Its characteristics let consumers realize the e-commerce live streaming's advantage of 'What you see is what you get', which shortens the distance between consumers and products, and gives consumers a unique but real shopping experience. Simultaneously, the live streamers of e-commerce platforms will also use a series of skills to enhance the real sense of product information dissemination. For instance, if live streamers are about to sell clothes, they will mark their height and weight and try clothes on, so that consumers can have a further understanding of the clothing information based on the real data. It will reduce the fitting errors from not trying cloth at present. The form of e-commerce live streaming effectively reduces the barriers in the process of information dissemination and lets users become the first-level information receivers, at the same time, the reliability of information is also improved.

\subsection{Improve Consumers' Shopping Environment}

In addition to the lack of interaction, traditional e-commerce also has another significant disadvantage: lack of social behavior and shopping atmosphere. Social behavior here means communicating with each other, and the shopping atmosphere means a lively atmosphere when buying on-site. However, in contrast, live stream shopping has these characteristics. When watching a live stream, viewers can make comments, give tips and gifts to streamers, there are also some reminders on the screen like 'XXX is buying the product' and significant discounts and coupons for the viewers. It can, on the one hand, increase user activity, and on the other hand, trigger consumers' desire to purchase.

\subsection{Increase Interaction and Communication}

E-commerce platforms use live streaming to gather the user's attention into the live room, closely connecting customers and products and facilitating interaction between consumers and live streamers. Traditional e-commerce generally uses pictures and texts to display product information. Under this situation, consumers obtain limited and visual information about products which leads to information asymmetry where information is unidirectional, and consumers are passive. However, e-commerce live streaming can exchange information in a visual face-to-face way between anchors and consumers because they can communicate in real-time. No matter what consumers want to know, they can give timely feedback to the anchor. The anchor will answer according to the user's needs, and consumers can actively choose the information they need to obtain.

The process of information dissemination is mainly composed of five essential elements: disseminator, media, content, audience, and feedback [5]. During e-commerce live streaming, the anchor is the disseminator, the platform is the media, product information is the content, viewers, and consumers are the audience, and the real-time interaction between the consumers and the anchors is the feedback. In daily communication, it takes a while for the disseminator to receive user feedback. For example, many consumers may evaluate the products on the platform after a period of use, but the information provided is no longer current, the demand of users may already have been changed. In contrast, the real-time interactivity of e- 
commerce live streaming platforms guarantees the timeliness of information feedback. Sellers can receive consumer feedback or opinions on products at the same time, which is convenient for them to edit and modify products or services in real-time. Simultaneously, timely obtainment of user needs can adjust the supply of commodities, which can effectively avoid product surplus.

\subsection{Determine Target Consumers More Accurately}

Nowadays, commercial advertisements exist everywhere. However, many people are averse to the massive amount of advertising information, and the desired effect may not be achieved. E-commerce live streaming has transformed the form of advertisements by displaying the original advertising content in the form of live streaming and interacting genuinely with viewers. The new way of information transmission cannot only bring freshness to consumers but also be more easily be adopted. Therefore, advertising effectiveness can be more easily reached through e-commerce.

At the same time, e-commerce live streaming can accurately determine the target consumer group. The viewers who first enter the live room tend to be the ones who are sufficiently interested in the products. Therefore, e-commerce live streaming effectively gathers those people who have the same purchase intention. According to 'Uses and Gratifications Theory', users are individuals whose motivation clearly comes with specific needs, which is the reason they contact the media. They are going to show interest in a specific product through multiple interactions with the anchor, and the anchor can also accurately understand the users' demand. In this way, the transaction between consumers and sellers can more easily be completed.

\subsection{High GMV Conversion Rate}

GMV (Gross Merchandise Volume) conversion rate is one of the most concerning data for each e-commerce participant. If the traffic brought by the platform through various marketing methods does not lead to the growth of GMV, then the marketing methods cannot be considered as effective leading tools. Traditional e-commerce is facing the exact problem of a low GMV conversion rate. Generally, the conversion rate fluctuates between 5\% and $10 \%$ [18]. Coupled with the increasing cost of attracting traffic, the amount of profit that ecommerce platforms can obtain decreases. However, the situation is getting improved by implementing the new marketing method of 'e-commerce plus live streaming'. Taobao claimed that it had a 65\% conversion rate across live streaming in 2018 [19]. The new model of 'e-commerce plus live streaming' has created a new type of e-commerce with strong user stickiness and a high conversion rate, which has developed a new profitable approach for traditional e-commerce.

\section{$6 \quad$ Problems and Development Strategies}

\subsection{Problems of e-Commerce Live Streaming Platforms}

For further development of e-commerce live streaming, there are some obstacles that need to be removed:

\subsubsection{Information Asymmetry}

Compared with traditional e-commerce shopping, consumers can understand products through live streaming more intuitively, which helps them reduce the possibility of buying fake and inferior products. However, due to information asymmetry, consumers will still encounter the problem of 'The video is for reference only'. Some unscrupulous merchants displayed quality products during a live stream but sold fake goods in contrast. 


\subsubsection{Unsatisfied after-Sales Service}

The potential targets coming with e-commerce live streaming are not only increasing sales but also increasing return rates. Taking the clothing business as an example, the return rate of clothing in traditional offline stores is less than 3\%, but the return rate of e-commerce is as high as $30 \%$, and the rate on large shopping festivals such as Double 11 is way higher [20].

\subsubsection{Lack of Excellent e-Commerce Live Streamers}

E-commerce live streamers interact with viewers through various live streaming techniques to gain their trust to complete the sales of goods, which is a job with high professional requirements. The development of an excellent e-commerce live streamer is not an easy task, which requires long-term practice and practice.

\subsubsection{Consumer Stickiness Is Still Not High Enough}

The e-commerce platform itself has insufficient consumer stickiness because the purchase of a certain product is a low-frequency behavior. For some consumers, browsing graphic information may already meet the needs of understanding product information, so there is no need to watch the live stream. Besides, watching live streams requires a particular time cost, which also declines consumer stickiness of e-commerce live streaming.

\subsection{Development Strategies and Suggestions}

According to the problems mentioned above, there are some recommended strategies for better development of e-commerce live streaming in the future:

\subsubsection{Improve Content Quality and Strengthen Platform Supervision}

Currently, on the e-commerce live streaming platform, random content is mainly produced in a UGC (User Generated Content) way. E-commerce live streaming platforms should establish more PGC (Professional Generated Content) content production models because professional content has a higher commercial value and attractiveness. The e-commerce live streaming platform can create its own IP (Intellectual Property) program and develop viewers' habit of watching the program regularly. Once enough viewers are attracted, the product advertisements can be implanted to obtain a better conversion rate. Simultaneously, platforms should also promote small merchants to produce content in the way of PGC. Only in this way could improve the quality of the entire platform. E-commerce platforms should also train merchants regularly to produce live content professionally and develop relevant system courses based on their own characteristics. Platforms could make comprehensive use of online and offline training to enhance merchants' ability to produce professional live content, thereby improving the entire platform's content quality. Also, the e-commerce platforms should include a stricter content review mechanism and gradually open the limits of authority to the merchants who have participated in the training. Through this review mechanism, on the one hand, the quality of the platform's overall live content can be improved, and on the other hand, it can strengthen the control right of platforms and evaluate the training results simultaneously.

\subsubsection{Improve the Product Quality and Consumers' Viewing Experience}

The first thing to enhance consumer stickiness is to accumulate word-of-mouth. Therefore, the quality of products should still be given top priority. Having quality control always comes first if merchants want to win consumers' trust. 
Besides, live streamers should re-edit the content after the live stream and replay the video as soon as possible to reach viewers who have not watched it before. Apart from this, streamers should also encourage consumers to ask questions and share pictures after buying, so that they can extend the period of a live stream to let target consumers stay longer in this live stream and enhance the consumer stickiness.

\subsubsection{Combination of KOL and Internet Celebrities}

During the shopping festival of August 18 in 2016, SUNING combined Internet celebrities and KOLs to let them do live stream together. During the live event of fewer than two hours, the number of online viewers reached 7.21 million with millions of interactions. Internet celebrities can bring much popularity to e-commerce live streaming, but they are not very good at shopping guides because they do not have a thorough understanding of product information and selling skills; in that matter, they cannot provide professional product purchase information. To make use of the influence of Internet celebrities and reach professional shopping guides at the same time, SUNING adopted the model of 'Internet celebrities plus KOL'. Internet celebrities are responsible for bringing popularity and enlivening atmosphere; KOLs are responsible for providing valuable and practical purchase information. A combination of such has achieved an excellent live streaming effect.

\subsubsection{Improve Users' Shopping Experience}

User experience (UE) is all the subjective feelings users have when using a product or service. Consumers usually have psychological expectations before using a product or service. If the actual experience exceeds this expectation, they will be satisfied and may establish loyalty. During an e-commerce live streaming, a pleasant shopping experience would make consumers prefer to use this product and improve the reputation of the platform and brand.

First, the e-commerce live streaming platform can improve its fluency because the user experience of the APP directly relates to the user's evaluation of the live stream. Platforms should continuously optimize the fluency to avoid serious product experience issues such as video freezing or delays.

The traditional way of online shopping has made people accustomed to it, with no surprises at all. Platforms should make good use of high technologies to improve users' shopping experience. For example, the introduction of high-tech such as AR, VR, image processing, etc., will be good fits to enhance consumers' shopping experience in terms of visual sense, further deepening their understanding of the product to make a reasonable purchase decision.

\section{Conclusion}

The core understanding of 'Live streaming plus E-commerce' as a new e-commerce model, is that e-commerce platforms use live streaming to sell. It brings massive traffic to the ecommerce platforms, achieving the purpose of gathering people's attention, and improving the conversion rate of the shopping carnivals. Besides, e-commerce platforms can obtain consumer feedback as soon as possible, thereby gaining a greater understanding of consumers. However, the e-commerce live streaming industry also has many drawbacks, such as lack of professional live streamers, low consumer stickiness, weak after-sales services, etc.

Currently, in China, the live streaming industry has entered a stage of steady development. To achieve further development, it needs to get rid of the above-mentioned barriers.

Under new media marketing, e-commerce live streaming is a kind of inevitable development trend. Its direction of reform urgently needs to be clarified. 
How to convert the influence of KOL into lasting purchasing power? How to increase the conversion rate and retention rate? How to maximize the fan value of influencers?

The authors make corresponding development strategies and suggestions for e-commerce live streaming based on the survey result and industry reports:

1. improving content quality and strengthen platform supervision,

2. improving the product quality and consumers' viewing experience,

3. combining KOLs and Internet celebrities, and

4. improving users' shopping experience.

With the application of image recognition, artificial intelligence, machine learning, and other technologies, e-commerce live streaming platforms will achieve further development. However, it should always be recognized that only doing a good job of product selection and ensuring the product quality can accumulate a good reputation for the entire platforms and better achieve their business goals.

\section{Acknowledgments}

In the process of writing this article, the authors have received a great deal of support and assistance. We sincerely thank several our relatives, friends, and supervisors for their encouragement and guidance.

The author Yang Lu would like to thank especially her supervisors, Prof. Dr. Yuping Jia and Prof. Dr. Heiko Karle, who always kept communicating with her in a timely manner during her writing process of more than 2 months and provided her with much support and guidance.

Secondly, she would like to thank her friend, Zehao Dong, for giving her lots of useful suggestions in the early stage of her article preparation and brainstorming with her together. Particularly, Yang would like to thank him for supporting her in modifying the grammar and format of her article in the later stage.

Finally, Yang would like to thank her partner Prof. Dr. Patrick Siegfried, for providing lots of assistance and great ideas as the second author.

\section{Literature}

[1] CHINA INTERNET NETWORK INFORMATION CENTER (CNNIC): The 45 Statistical Report on Internet Development in China. [online]. 2020. [accessed 2020-0702]. Available from http://www.cnnic.cn/gywm/xwzx/rdxw/20172017_7057/202004/t20200427_70973.htm

[2] IIMEDIA RESEARCH: The Development status of China's live streaming e-commerce and significant data monitoring and analysis. [online]. 2020. [accessed 2020-07-02]. Available from WWW: https://www.iimedia.cn/c400/68945.html

[3] IIMEDIA RESEARCH: China's live streaming e-commerce report. [online]. 2020. [accessed 2020-07-02]. Available from https://www.iimedia.cn/c460/69068.html

[4] ZHANG, J.: Research on the Current Situation and Development Strategy of Ecommerce Live streaming Platform. [online]. China, Changchun: Changchun University of Technology, 2018. [accessed 2020-07-03]. Available from WWW: http://cdmd.cnki.com.cn/Article/CDMD-10190-1018818344.htm 
[5] LIU, J.: Research on E-commerce Live streaming from the Perspective of Communication. [online]. China, Nanchang: Nanchang University, 2018. [accessed 2020-07-03]. Available from WWW: https://cdmd.cnki.com.cn/article/cdmd-104031018148461.htm

[6] McCOMBS, M. E.; SHAW, D. L.: The Agenda-Setting Function of Mass Media. In: Protess, D.; McCombs, M. E. (eds.), Agenda Setting. 1991. eBook ISBN 9781315538389. DOI: $10.4324 / 9781315538389-8$

[7] LIU, K.; YOU, Y.: Research Overview of the KOL Theory. [online]. 2009. [accessed 2020-07-03]. Available from WWW: https://m.xzbu.com/7/view-2953169.htm

[8] NOELLE-NEUMANN, E.: The spiral of silence a theory of public opinion. Journal of communication. 1974, Vol. 24, Issue 2, pp. 43-51.

[9] ROSSI, E.: Uses \& Gratifications/ Dependency Theory. [online]. 2002. [accessed 202007-04]. Available from WWW: http://zimmer.csufresno.edu/ johnca/spch100/7-4uses.htm

[10] NATIONAL BUREAU OF STATISTICS OF CHINA: The Average Annual Wage of Persons Employed in Urban Non-private Units In 2019. [online]. 2020. [accessed 202007-04]. Available from

WWW: http://www.stats.gov.cn/english/PressRelease/202005/t20200518_1746112.html

[11] CINIC: Post-95 become the new main force of installment buying. [online]. 2019. [accessed 2020-07-05]. Available from http://www.cinic.org.cn/zgzz/qy/662789.html?from=singlemessage

[12] STATISTA: Snack Food, China. [online]. 2020. [accessed 2020-07-05]. Available from WWW: https://www.statista.com/outlook/40100300/117/snack-food/china

[13] ZHUANG, S.: How do the five categories perform in live e-commerce. [online]. 2020. [accessed 2020-07-05]. Available from http://www.woshipm.com/it/3490364.html

[14] ZHIHU: Is e-commerce live streaming a 'future trend' or a 'temporary excitement'. Where is the growth point in 2020. [online]. 2020. [accessed 2020-07-05]. Available from WWW: https://www.zhihu.com/question/357691481/answer/1296682959

[15] STATISTA: Share of the most common e-commerce complaint issues in China in $1^{\text {st }}$ quarter of 2020. [online]. 2020. [accessed 2020-07-05]. Available from WWW: https://www.statista.com/statistics/1066658/china-share-of-most-popular-ecommercecomplaint-issues/

[16] COSMETICS CHINA: How to Sell 10,000 Lipsticks in 2 Hours in China. [online]. n.d. [accessed 2020-07-06]. Available from WWW: https://cosmeticschinaagency.com/sell10000-lipsticks-2-hours-china/

[17] IIMEDIA RESEARCH: Research Report on China's Online Live streaming Industry in the First Half of 2019. [online]. 2019. [accessed 2020-07-07]. Available from WWW: https://www.iimedia.cn/c400/65966.html

[18] LI, Y.: Introduction of Conversion rate. [online]. 2012. [accessed 2020-07-07]. Available from WWW: http://www.360doc.com/content/12/1029/14/9934_244455229.shtml 
[19] CORESIGHT RESEARCH: Retail 2020: 10 Trends for China E-commerce. [online]. 2020. [accessed 2020-07-07]. Available from WWW: https://coresight.com/research/retail-2020-10-trends-for-china-e-commerce/

[20] FANG, Y.: Why is the return rate of live streaming products so high. [online]. 2020. [accessed 2020-07-18]. Available from https://www.sohu.com/a/395305748_121339 


\section{ŽIVÝ PŘENOS ELEKTRONICKÉHO OBCHODOVÁNÍ - ROZVÍJEJÍCÍ SE PRU゚MYSL V ČÍNĚ}

\section{A POTENCIÁLNÍ BUDOUCÍ TREND VE SVĚTĚ}

Vzhledem k širokému použíání Internetu se mnoho průmyslových odvětví rychle rozvíjí. Ekonomika založená na Internetu představuje významnou hrozbu pro tradiční ekonomiku. Živé vysílání plus elektronický obchod, který je považován za současnou globální ekonomickou situaci, je výsledkem kombinace živého vysílání a různých průmyslových odvětví prostřednictvím Internetu.

Živý přenos elektronického obchodu je jedním z nejdůležitějších typů online živého přenosu. $\mathrm{V}$ tomto článku je definován jako živý přenos platformy elektronického obchodování používaný KOL nebo prodejci produktů prostřednictvím vestavěné funkce živého vysílání platformy k propagaci zboží, značek, událostí atd. k dosažení cílů expozice značky a prodej produktů. Tento druh marketingového nástroje nyní převládá. V živém přenosu elektronického obchodování však existuje mnoho nedostatků, které je třeba zlepšit, protože vývoj elektronického obchodování je nezralý a dohled nad používáním Internetu stále probíhá.

\section{E-COMMERCE LIVE STREAMING - EINE AUFSTREBENDE BRANCHE IN CHINA UND EIN POTENZIELLER ZUKÜNFTIGER TREND IN DER WELT}

Mit der weit verbreiteten Nutzung des Internets haben sich viele Branchen rasant entwickelt. Die auf dem Internet basierende Wirtschaft stellt eine erhebliche Bedrohung für die traditionelle Wirtschaft dar. Live-Streaming plus E-Commerce, der als aktueller globaler Wirtschaftsstatus anerkannt ist, ist das Ergebnis der Kombination von Live-Streaming und verschiedenen Branchen über das Internet.

E-Commerce-Live-Streaming ist eine der wichtigsten Arten des Online-Live-Streamings. In diesem Artikel wird es als Live-Streaming der E-Commerce-Plattform definiert, die von Meinungsführern oder Produktverkäufern über die integrierte Live-Streaming-Funktion der Plattform zur Verbreitung von Waren, Marken, Ereignissen usw. verwendet wird, um die Ziele der Markenbekanntheit zu erreichen und Produktverkäufe. Diese Art von Marketinginstrument ist mittlerweile weit verbreitet. Es gibt jedoch viele Mängel, die verbessert werden müssen, da die Entwicklung des E-Commerce noch nicht ausgereift ist und die Überwachung der Internetnutzung noch nicht abgeschlossen ist.

\section{E-COMMERCE LIVE STREAMING - WSCHODZĄCA BRANŻA W CHINACH I POTENCJALNY PRZYSZŁY TREND NA ŚWIECIE}

Wraz z upowszechnieniem się Internetu nastąpił gwałtowny rozwój wielu gałęzi przemysłu. Gospodarka oparta na Internecie stanowi znaczące zagrożenie dla tradycyjnej gospodarki. Transmisja na żywo (live streaming) oraz handel elektroniczny, który jest uznawany za obecną globalną sytuację gospodarczą, są wynikiem połączenia transmisji na żywo i różnych branż przemysłowych za pośrednictwem Internetu.

Transmisja na żywo w handlu elektronicznym jest jednym z najważniejszych rodzajów transmisji na żywo online. W niniejszym artykule zdefiniowano to jako transmisję na żywo platformy e-commerce używanej przez KOL lub sprzedawców produktów za pośrednictwem wbudowanej funkcji transmisji na żywo platformy w celu promowania towarów, marek, wydarzeń itp. w celu osiągnięcia celów związanych $\mathrm{z}$ prezentacją marki i sprzedażą produktów. Ten rodzaj narzędzia marketingowego jest obecnie dominujący. W live streamingu istnieje jednak wiele niedociągnięć, które wymagają poprawy, ponieważ rozwój handlu elektronicznego jest niedojrzały, a nadzór nad korzystaniem z Internetu jest w toku. 